\title{
Ticks (Acari: Ixodidae) on Wild Animals from the Porto-Primavera Hydroelectric Power Station Area, Brazil
}

\author{
Marcelo B Labruna $/{ }^{+}$, Cátia D de Paula*, Thiago F Lima**, Dênis A Sana*** \\ Departamento de Medicina Veterinária Preventiva e Saúde Animal, Faculdade de Medicina Veterinária e Zootecnia, Universidade \\ de São Paulo, Cidade Universitária, Av. Prof. Orlando Marques de Paiva 87, 05508-000 São Paulo, SP, Brasil *Centro de \\ Conservação da Fauna Silvestre de Ilha Solteira **Unidade de Manejo de Fauna Silvestre de Presidente Epitácio, Companhia \\ Energética de São Paulo, São Paulo, SP, Brasil ***Associação para a Conservação dos Carnívoros Neotropicais, \\ São Paulo, SP, Brasil
}

From June 2000 to June 2001, a total of 741 ticks were collected from 51 free-living wild animals captured at the Porto-Primavera Hydroelectric power station area, located alongside an approximately $180 \mathrm{~km}$ course of the Paraná river, between the states of São Paulo and Mato Grosso do Sul, comprising 9 species of 3 genera: Amblyomma (7 species), Boophilus (1) and Anocentor (1). A total of 421 immature Amblyomma ticks were reared in laboratory until the adult stage, allowing identification of the species. A. cajennense was the most frequent tick species (mostly immature stages) collected on 9 host species: Myrmecophaga tridactyla, Tamandua tetradactyla, Cerdocyon thous, Puma concolor, Tayassu tajacu, Mazama gouazoubira, Hydrochaeris hydrochaeris, Alouatta caraya, Cebus apella. Other tick species were less common, generally restricted to certain host taxa.

Key words: ticks - wildlife - Amblyomma - Boophilus - Anocentor - Brazil

Ticks are obligate blood feeders that parasitize a wide variety of terrestrial and flying vertebrates and a few marine snakes and lizards (Hoostraal 1985). More than 800 tick species have been described in the world (Keirans 1992, Camicas et al. 1998). Ticks are vectors of more kinds of microorganisms than any other arthropod taxon, including mosquitoes (Hoogstraal 1985, Oliver 1989). The vast literature regarding ticks has centered mostly around $10 \%$ of the world tick fauna, which have been well recognized for their medical and veterinary significance. However, a comprehensive knowledge of the ecology of "important" ticks and tick borne-diseases are best achieved by knowing the biological and physiological similarities and differences between all species, in relation to their hosts and to the environment. Knowledge of biological models of tick parasitism of wildlife is very useful to clarify factors that have permitted a few tick species to become economically important pests and vectors of disease agents to man and animals (Hoogstraal 1985).

There are 54 valid tick species in Brazil, of which 32 belong to the genus Amblyomma (Guimarães et al. 2001). Although more than half of the 102 known Amblyomma species in the World are endemic to the New World (Keirans 1992), they have been poorly studied. For many Brazilian species, geographic and host records are scarce and new tick species have recently been discovered (Barros Battesti et al. 1999, Labruna et al. 2002a). Although all tick species reported in Brazil have been properly described in the adult stage, immature stages (larvae and nymphs) of most of them are still unknown. Thus, host records for immature stages of the majority of the Amblyomma species from Brazil are even more scarce. This

$\overline{{ }^{+} \text {Corresponding author. Fax }}$ +55-11-3091.7928. E-mail: labruna@usp.br

Received 16 April 2002

Accepted 26 August 2002 situation is linked to the lack of a taxonomic keys for identification of Amblyomma immature stages in Latin America. Currently, the only conclusive means of identifying species of Amblyomma immature stages from Brazil are by rearing these ticks until the adult stage, or by the use of specific molecular markers (Marrelli et al. 2001).

The present study reports ticks infesting several wildlife species captured alongside the Paraná river, Brazil. Several Amblyomma immature stages were collected and reared until the adult stage in the laboratory, allowing conclusive identification of the species.

\section{MATERIALS AND METHODS}

Porto-Primavera Hydroelectric power station is located in Brazil between the southwest of the state of São Paulo and the east of the state of Mato Grosso do Sul. Its water reservoir, filled up by the Paraná river, flooded an area of $2,200 \mathrm{~km}^{2}$ at the São Paulo and Mato-Grosso do Sul border (Szabó et al. 2002). During the flooding, some freeliving wild animals were rescued for an extensive research program with the financial support of the São Paulo State Energy Company (Cesp). The flooded area was composed of an extensive flat swamp, interposed by areas of dense forest above high-water level. Altitude ranged from 276 to $328 \mathrm{~m}$ above sea level.

For the present study, a total of 51 animals was sampled, comprising 15 different species (Table) from the following municipalities: Anaurilândia, Bataguassu, Bataiporã, Brasilândia, Santa Rita Pardo in Mato Grosso do Sul; Presidente Epitácio, Primavera and Rosana in São Paulo. All these municipalities are contiguously located alongside an approximately $180 \mathrm{~km}$ course of the Paraná river, between Brasilândia $\left(21^{\circ} 15^{\prime} \mathrm{S}, 52^{\circ} 01^{\prime} \mathrm{W}\right)$ and Rosana $\left(22^{\circ} 33^{\prime} \mathrm{S}, 5^{\circ} 01^{\prime} \mathrm{W}\right)$. Captures were carried out at irregular intervals from June 2000 to June 2001, a period when flooding procedures were divided into stages.

Captured animals were restrained with or without anesthesia (depending on animal species), and given a thor- 
ough physical examination. As other biological samples were taken for other research projects, tick sampling was performed on a limited period of $3 \mathrm{~min} / \mathrm{host}$. After this procedure, animals were taken to several Brazilian zoos, authorized breeders, or experimental reintroduction areas.

Ticks collected on the animals were immediately placed in dry plastic vials containing few fresh grass leaves, and covered by a cork containing several minute holes. Vials were properly identified and conditioned under room temperatures for few days or weeks, and then they were sent to the laboratory. The purpose of this procedure was to try to maintain ticks alive inside the vials until arriving at the laboratory for taxonomic identification.

Engorged larvae or nymphs that arrived alive at the laboratory were immediately placed in an incubator at $25^{\circ} \mathrm{C}$ and RH $85 \%$, to allow them to molt to nymphs and adults, respectively. Nymphs obtained from the engorged larvae were infested on naive rabbits according to Pinter et al. (2002). Adults obtained from the engorged nymphs were used for identification of the species of the former immature ticks collected on the animals.

\section{RESULTS}

A total of 741 ticks were collected from the 51 animals (Table). Nine tick species were identified, comprising 3 genera: Amblyomma (7 species), Boophilus (1) and Anocentor (1). From 495 nymphs and 77 larvae of the genus Amblyomma collected from the animals, a total of 413 and 8 , respectively, were successfully reared until the adult stage in the laboratory, allowing identification of the species. The remaining 82 nymphs and 69 larvae died before reaching the adult stage, and were identified only to their generic level (Amblyomma sp.).

A. cajennense was the most frequent tick species, collected on 9 host species of different mammal taxa (Edentata, Carnivora, Artiodactyla, Rodentia and Primates). All these hosts harbored only immature stages of A. cajennense, except for one Edentata species (Myrmecophaga tridactyla) and one Artiodactyla (Tayassu tajacu), on which adults of $A$. cajennense were additionally found. Other Amvblyomma species were generally found in the adult stage, restricted to certain host taxa: A. rotundatum on snakes (Bothrops moojeni and Boa constrictor), A. nodosum on anteaters (M. tridactyla and Tamandua tetractyla), A. cooperi on capybara (Hydrochaeris hydrochaeris) and A. longirostre on porcupine (Coendou prehensilis). Representative specimens of all ticks species of the present study have been deposited in the National Tick Collection of Faculdade de Medicina Veterinária e Zootecnia, Universidade de São Paulo (nos: 302, 326, $327,329,332-349,351,352,447,448,462,463,475-477,488$, 489, 575).

\section{DISCUSSION}

Our results showed that $A$. cajennense was the most common tick species in the studied area. This species is endemic to the Neotropical region, where it seems to be primarily a parasite of large wild mammals, especially tapirs (Tapirus terrestris), capybaras (H. hydrochaeris), peccaries (Tayassu spp.) (Aragão 1911, 1936). Horses, which were introduced into New World during colonization, have been showed to act as primary hosts for all parasitic stages of A. cajennense (Oliveira 1998, Labruna et al. 2002b). Cattle, another introduced host, was also showed to be a suitable host for A. cajennense (Fairchild et al. 1966, Serra-Freire 1982). During the present study, many farms alongside the Paraná river were visited and those provided shared areas by horses, cattle and wild animals. In addition, tapirs were also present in these areas (unpublished data). We believe that our results of $A$. cajennense on a great variety of wild animals (Table) can be linked to the availability of several primary hosts for A. cajennense (horse, cattle, tapir, capybara, peccary). Although a variety of animal species and also humans can be infested by A. cajennense (Aragão 1936, Lopes et al. 1998, Pereira et al. 2000, present study), the abundance of the infestations will depend on the availability of the primary hosts for the tick. In addition, environmental conditions of the area must have been favorable for the freeliving stages of $A$. cajennense in the present study. It has been shown that this tick is very sensitive to vegetation cover (Labruna et al. 2001a).

The cattle tick, B. microplus, was collected from marsh deer (Blastocerus dichotomus) and jaguar (Panthera onca). This tick is highly prevalent on cattle in almost all of Brazil (Horn 1983). It is an Old World tick that was probably introduced in Brazil with cattle (Aragão 1911). Several studies have reported infestations by B. microplus on wild and domestic hosts other than cattle, but in all cases these hosts have a history of sharing the same area with cattle (Labruna et al. 2001a,b). Another study, conducted simultaneously on the same area of the present study, showed that $B$. microplus was the main tick species infesting four populations of marsh deers (Szabó et al. 2002). So far, cattle is the only known primary host for B. microplus in Brazil and should be viewed as the main source of B. microplus for any other host species. Similarly, horses are primary hosts for A. nitens over Northern, Central and Southeastern Brazil (Aragão \& Fonseca 1953, Labruna et al. 2001a) and the finding of this tick on marsh deer in the present study should be linked to the presence of infested horses in the studied area.

A. nodosum was the most common adult tick on both anteaters species, $M$. tridactyla and $T$. tetractyla. To our knowledge, adults of this species have been reported exclusively on anteaters (Aragão 1936, Fairchild et al. 1966, Jones et al. 1972, Guimarães et al. 2001). In the present study, all 304 adult ticks that molted from engorged nymphs collected on anteaters were identified as $A$. cajennense. Thus, information about hosts for $A$. nodosum immature stages remains lacking.

The present record of A. triste on M. tridactyla (Table) is the first of this tick on an Edentata. It should not be considered unusual as the adult stage of A. triste has shown a broad host range in Uruguay (Sampaio et al. 1992). However, marsh deer seem to be the primary hosts for the adult stage of A. triste in Brazil (Szabó et al. 2002). The taxonomic position of $A$. triste was formerly confused with A. tigrinum and A. maculatum in South America (Kohls 1956). It is probable that $A$. maculatum does not exist in Brazil and adults of A. tigrinum parasitize almost exclusively Carnivora hosts (Guglielmone et al. 2000). As this last species is morphologically very similar to $A$. triste, previous reports of A. tigrinum on marsh deer in Brazil 
TABLE

Ticks collected from wild animals in the Primavera hydroelectric power station area, Brazil

\begin{tabular}{|c|c|c|c|c|c|c|c|c|}
\hline \multirow{2}{*}{ Name (n) } & \multirow{2}{*}{$\begin{array}{c}\text { Host } \\
\text { No. infested/No. non-infested host }\end{array}$} & \multirow{2}{*}{$\begin{array}{l}\text { Tick } \\
\text { species }\end{array}$} & \multicolumn{5}{|c|}{ Number of ticks } & \multirow{2}{*}{$\begin{array}{l}\text { Mean no. of ticks } \\
\pm \mathrm{SE} \text { (range) }\end{array}$} \\
\hline & & & Males & Females & Nymphs & Larvae & Total & \\
\hline \multicolumn{9}{|l|}{ REPTILA } \\
\hline Bothrops moojeni (1) & $1 / 0$ & Amblyomma rotundatum & - & 1 & - & - & 1 & $1 \pm 0.0(1)$ \\
\hline \multirow[t]{2}{*}{ Boa constrictor $(1)$} & $1 / 0$ & A. rotundatum & - & 1 & - & - & 1 & $1 \pm 0.0$ \\
\hline & $1 / 0$ & Amblyomma sp. & - & - & 7 & 2 & 9 & $9 \pm 0.0(9)$ \\
\hline \multicolumn{9}{|l|}{ EDENTATA } \\
\hline \multirow[t]{4}{*}{ Myrmecophaga tridactyla (20) } & $18 / 2$ & A. cajennense & 24 & 12 & $270^{a}$ & - & 306 & $15.3 \pm 14.2(0-54)$ \\
\hline & $12 / 8$ & A. nodosum & 45 & 7 & - & - & 52 & $2.6 \pm 4.4(0-18)$ \\
\hline & $1 / 19$ & A. triste & - & 1 & - & - & 1 & $0.05 \pm 0.2(0-1)$ \\
\hline & $11 / 9$ & Amblyomma sp. & - & - & 30 & - & 30 & $1.5 \pm 2.2(0-6)$ \\
\hline \multirow[t]{3}{*}{ Tamandua tetradactyla (5) } & $4 / 1$ & A. cajennense & - & - & $34^{a}$ & - & 34 & $6.8 \pm 7.6(0-18)$ \\
\hline & $4 / 1$ & A. nodosum & 21 & 7 & - & - & 28 & $5.6 \pm 9.2(0-22)$ \\
\hline & $1 / 4$ & Amblyomma sp. & - & - & 1 & - & 1 & $0.2 \pm 0.4(0-1)$ \\
\hline \multicolumn{9}{|l|}{ CARNIVORA } \\
\hline Cerdocyon thous (1) & $1 / 0$ & A. cajennense & - & - & $3^{a}$ & - & 3 & $3 \pm 0.0(3)$ \\
\hline \multirow[t]{3}{*}{ Puma concolor (2) } & $1 / 1$ & A. cajennense & - & - & - & $8^{b}$ & 8 & $4 \pm 5.6(0-8)$ \\
\hline & $1 / 1$ & A. coelebs & - & - & $1^{a}$ & - & 1 & $0.5 \pm 0.7(0-1)$ \\
\hline & $2 / 0$ & Amblyomma sp. & - & - & - & 63 & 63 & $31.5 \pm 19.0(18-45)$ \\
\hline \multirow[t]{2}{*}{ Panthera onca (2) } & $2 / 0$ & Boophilus microplus & - & - & 8 & - & 8 & $4 \pm 4.2(1-7)$ \\
\hline & $2 / 0$ & Amblyomma sp. & - & - & 1 & 2 & 3 & $1.5 \pm 0.7(1-2)$ \\
\hline \multicolumn{9}{|l|}{ ARTIODACTYLA } \\
\hline \multirow[t]{2}{*}{ Tayassu tajacu (5) } & $5 / 0$ & A. cajennense & 6 & 1 & $23^{a}$ & - & 30 & $6 \pm 5.7(1-15)$ \\
\hline & $3 / 2$ & Amblyomma sp. & - & - & 10 & - & 10 & $2 \pm 2.5(0-6)$ \\
\hline \multirow[t]{2}{*}{ Mazama gouazoubira (1) } & $1 / 0$ & A. cajennense & - & - & $5^{a}$ & - & 5 & $5 \pm 0.0(5)$ \\
\hline & $1 / 0$ & Amblyomma sp. & - & - & 3 & - & 3 & $3 \pm 0.0(3)$ \\
\hline \multirow[t]{2}{*}{ Blastocerus dichotomus (1) } & $1 / 0$ & B. microplus & - & 4 & - & - & 4 & $4 \pm 0.0$ \\
\hline & $1 / 0$ & Anocentor nitens & 1 & 1 & - & - & 2 & $2 \pm 0.0(2)$ \\
\hline \multicolumn{9}{|l|}{ RODENTIA } \\
\hline Coendou prehensilis (3) & $3 / 0$ & A. longirostre & 5 & - & - & - & 5 & $1.6 \pm 0.5(1-2)$ \\
\hline \multirow[t]{3}{*}{ Hydrochaeris hydrochoeris (3) } & $3 / 0$ & A. cooperi & 14 & 10 & $39^{a}$ & - & 63 & $21 \pm 13.1(7-33)$ \\
\hline & $1 / 2$ & A. cajennense & - & - & $1^{a}$ & - & 1 & $0.3 \pm 0.6(0-1)$ \\
\hline & $3 / 0$ & Amblyomma sp. & - & - & 3 & 1 & 4 & $1.3 \pm 0.5(1-2)$ \\
\hline \multicolumn{9}{|l|}{ PRIMATES } \\
\hline \multirow[t]{2}{*}{ Alouatta caraya (3) } & $3 / 0$ & A. cajennense & - & - & $18^{a}$ & - & 18 & $6 \pm 5.6(1-12)$ \\
\hline & $2 / 1$ & Amblyomma sp. & - & - & 20 & 1 & 21 & $7 \pm 10.4(0-19)$ \\
\hline \multirow[t]{2}{*}{ Cebus apella (3) } & $3 / 0$ & A. cajennense & - & - & $19^{a}$ & - & 19 & $6.3 \pm 7.6(1-15)$ \\
\hline & $3 / 0$ & Amblyomma sp. & - & - & 7 & - & 7 & $2.3 \pm 1.1(1-3)$ \\
\hline
\end{tabular}

$a$ : species identification was carried out after nymphs had molted to the adult stage in the laboratory; $b$ : species identification was carried out after larvae had molted to nymphs that engorged on rabbits and molted to the adult stage in the laboratory. 
(Serra-Freire et al. 1996, Sinkoc et al. 1998, Pereira et al. 2000) should be re-evaluated.

The present records of adults of A. longirostre on porcupine, A. rotundatum on cold blooded hosts (snakes), and A. cooperi on capybaras are in agreement with the literature that reports these ticks, almost exclusively on these hosts (Aragão 1936, Jones et al. 1972, Evans et al. 2000, Guimarães et al. 2001). The finding of an A. coelebs nymph on puma ( $P$. concolor) is the first host record concerning an immature stage of this species. Adults of $A$. coelebs have been found on a variety of medium and large mammals, but tapirs seem to be its primary hosts (Fairchild et al. 1966, Jones et al. 1972, Guimarães et al. 2001).

Our findings reinforce previous studies, which showed the genus Amblyomma comprising the largest number of species parasitizing wildlife in Brazil (Aragão 1936, Sinkoc et al. 1998, Evans et al. 2000, Pereira et al. 2000, Guimarães et al. 2001, Labruna et al. 2002a). In addition, we found a variety of host records for immature stages of $A$. cajennense, much broader than for the adult stage. Further studies should emphasize host usage by Amblyomma immature stages, contributing to a better knowledge of life history of the New World Amblyomma fauna.

\section{ACKNOWLEDGMENTS}

To Companhia Energética de São Paulo for the field work support and to Ibama for permission to capture wild animals in the studied area.

\section{REFERENCES}

Aragão H 1911. Notas sobre ixódidas brazileiros. Mem Inst Oswaldo Cruz 3: 145-195.

Aragão H 1936. Ixodidas brasileiros e de alguns paizes limitrophes. Mem Inst Oswaldo Cruz 31: 759-843.

Aragão H, Fonseca F 1953. Notas de Ixodologia. VII Otocentor nitens (Neumann 1897) versus Anocentor columbianus Schulze 1937 e comentários sobre a rápida disseminação desse ixodídeo no Brasil (Acari: Ixodidae). Mem Inst Oswaldo Cruz 51: 499-501.

Barros-Battesti DM, Arzua M, Pichorim M. 1999. Registro de ocorrência de uma espécie nova de carrapato do gênero Ixodes Latreille (Acari: Ixodidae) para o Brasil. XI Seminário Brasileiro de Parasitologia Veterinária, Salvador, p.103

Camicas JL, Hervy JP, Adam F, Morel PC 1998. Les Tiques du Monde. Nomenclature, Stades Décrits, Hôtes, Repártition (Acarida, Ixodida), Orstom, Paris, 233 pp.

Evans DE, Martins JR, Guglielmone AA 2000. A review of the ticks (Acari: Ixodidae) of Brazil, their hosts and geographic distribution - 1. The state of Rio Grande do Sul, Southern Brazil. Mem Inst Oswaldo Cruz 95: 453-470.

Fairchild GB, Kohls GM, Tipton V 1966. The ticks of Panama. In RL Wenzel, VJ Tipton (eds), Ectoparasites of Panama, Field Museum Nat Hist, Chicago, p. 167-219.

Guglielmone AA, Mangold AJ, Luciani CE, Viñabal AE 2000. Amblyomma tigrinum (Acari: Ixodidae) in relation to phytogeography of central-northern Argentina with notes on hosts and seasonal distribution. Exp App Acarol 24: 983-989.

Guimarães JH, Tucci EC, Barros-Batttesti DM 2001. Ectoparasitos de Importância Veterinária, Plêiade, São Paulo, 213 pp.

Horn SC 1983. Prováveis Prejuízos Causados pelos Carrapatos, 2 ed., Boletim de Defesa Sanitária Animal, Ministério da Agricultura, Brasília, 79 pp.

Hoogstraal H 1985. Argasid and Nuttalliellid ticks as parasites and vectors. Adv Parasitol 24: 135-238.
Jones EK, Clifford CM, Keirans JE, Kohls GM 1972. The ticks of Venezuela (Acarina: Ixodoidea) with a key to the species of Amblyomma in the Western hemisphere. Brigham Young Univ Sci Bull Biol Ser 17: 1-40.

Keirans JE 1992. Systematic of the Ixodida (Argasidae, Ixodidae, Nutalliellidae): an overview and some problems. In B Fivaz, T Petney, I Horak (eds), Tick Vector Biology. Medical and Veterinary Aspects, Springer-Verlag, Berlin, p. 1-21.

Kohls GM 1956. Concerning the identity of Amblyomma maculatum, A. tigrinum, A. triste and A. ovatum of Koch, 1844. Proc Ent Soc Wash 58: 143-147.

Labruna MB, Basano AS, Schumaker TTS, Camargo LMA, Camargo EP 2002a. Fauna de carrapatos de Rondônia: Resultados parciais. XXXVIII Congresso da Sociedade Brasileira de Medicina Tropical, Foz do Iguaçu, p. 149.

Labruna MB, Kasai N, Ferreira F, Faccini JLH, Gennari SM 2002b. Seasonal dynamics of ticks (Acari: Ixodidae) on horses in the state of São Paulo, Brazil. Vet Parasitol 105: 65-77.

Labruna MB, Kerber CE, Ferreira F, Faccini JLH, De Waal DT, Gennari SM 2001a. Risk factors to tick infestations and their occurrence on horses in the State of São Paulo, Brazil. Vet Parasitol 97: 51-64.

Labruna MB, Souza SLP, Guimarães Jr JS, Pacheco RC, Pinter A, Gennari SM 2001b. Prevalência de carrapatos em cães de áreas rurais da região norte do Estado do Paraná. Arq Bras Med Vet Zootec 53: 553-556.

Lopes CML, Linardi PM, Botelho JR 1998. Ectoparasitos de roedores do município de Tiradentes, Minas Gerais. I. Ectoparasito fauna. Mem Inst Oswaldo Cruz 84: 333-334.

Marrelli MT, Marques RC, Souza LF, Labruna MB, Marinotti O, Schumaker TTS 2001. Utilização do segundo espaçador interno transcrito (ITS2) do DNA ribossômico no diagnóstico molecular de carrapatos do gênero Amblyomma (Fabricius, 1787). J Bras Patologia 37 (Supl. 4): 65.

Oliveira PR 1998. Amblyomma cajennense (Fabricius, 1787) (Acari: Ixodidae): Avaliação de Técnicas para o Estudo de Dinâmica Populacional e Biotecnologia, PhD Thesis, Universidade Federal de Minas Gerais, Belo Horizonte, 97 pp.

Oliver Jr JH 1989. Biology and systematics of ticks (Acari: Ixodida). Annu Rev Ecol Syst 20: 397-430.

Pereira MC, Szabó MJP, Bechara GH, Matushima ER, Duarte JMB, Rechav Y, Fielden L, Keirans JE 2000. Ticks (Acari: Ixodidae) associated with wild animals in the Pantanal region of Brazil. J Med Entomol 37: 979-983.

Pinter AS, Labruna MB, Faccini JLH 2002. Feeding period of males and females of Amblyomma cajennense (Acari: Ixodidae) under laboratory conditions, with special reference to sex ratio. Vet Parasitol 104: 79-88.

Sampaio I, Carballo M, Parietti S 1992. Comprobación de la presencia de Amblyomma triste (Acari, Ixodidae) en Uruguay. Bol Soc Zool Uruguay 7: 75-76.

Serra-Freire NM 1982. Ixodídeos parasitas de bovinos leiteiros na zona fisiográfica de Resende, Estado do Rio de Janeiro. Rev Bras Med Vet 5: 18-20.

Serra-Freire NM, Amorim M, Gazêta GS, Guerim L, Desidério MHG 1996. Ixodofauna de cervídeos no Brasil. Rev Bras Ciên Vet 3: 51-54.

Sinkoc AL, Brum JGW, Moraes W, Crawshaw P 1998. Ixodidae parasitos de animais silvestres na região de Foz do Iguaçu, Brasil e Argentina. Arq Inst Biol 65: 29-33.

Szabó MPJ, Labruna MB, Pereira MC, Duarte JMB 2002. Ticks (Acari: Ixodidae) on free-living Marsh-deer (Blastocerus dichotomus) populations from Southeast of Brazil: infestations prior and after environmental shrinkage by the dam from a hydroelectric power station. IV International Conference on Ticks and Tick-borne Pathogens, Baniff, Alberta, Canada, p. 62-63. 